\title{
An illustrated catalogue of the types of Blephariceridae (Diptera) in the collection of Museu de Zoologia da Universidade de São Paulo, Brazil
}

\author{
Leonardo Henrique Gil-Azevedo \& \& Carlos José Einicker Lamas² \\ 1 Universidade Federal do Rio de Janeiro (UFRJ), Museu Nacional (MN). Rio de Janeiro, RJ, Brasil. \\ ORCID: http://orcid.org/0000-0002-0389-2185. E-mail: Ihgazevedo@mn.ufrj.br (correspondig author) \\ 2 Universidade de São Paulo (USP), Museu de Zoologia (MZUSP). São Paulo, SP, Brasil. \\ ORCID: http://orcid.org/0000-0002-7750-590X. E-mail: einicker@usp.br
}

\begin{abstract}
Kelloggina Williston, 1907 is one of the least studied Blephariceridae genera in the world, despite being the most diverse in the Neotropics with 34 species. We provide a catalogue with the 14 nominal species of the genus described by Lane and d'Andretta from the Southeastern Region of Brazil, of which the type-specimens are deposited at the Diptera Collection of the Museu de Zoologia da Universidade de São Paulo. There are 60 specimens deposited at this museum, including male holotypes of 14 species and females "allotypes" (paratypes) for seven species. We include male diagnoses and photographs of the holotypes of all species.
\end{abstract}

Keywords. Type material; Taxonomy; Nomenclature; Scientific collections; Biodiversity.

\section{INTRODUCTION}

Blephariceridae comprises 30 genera and nearly 330 species worldwide (Courtney, 2017). Fragmentary studies in few poorly surveyed areas registered five genera and 76 species in the Neotropical Region so far (Gil-Azevedo, 2018), including the ill-defined genus Kelloggina Williston, 1907. This genus is one of the least studied blepharicerid groups in the world, despite being the most diverse in the Neotropics with 34 species. All are reported from southeastern region of Brazil to central region of Chile (Gil-Azevedo, 2018).

The first two species of Kelloggina were described at the end of the $19^{\text {th }}$ century, $K$. torrentium (Müller, 1881) and K. rufescens (Williston, 1893). Lutz (1920) described an additional 16 species from Rio de Janeiro, São Paulo, and Santa Catarina Brazilian states. After that, two further species were described based on male adults, K. brevicornia (Edwards, 1929) and K. chilena (Alexander, 1952), from Misiones, Argentina and Santiago, Chile, respectively (Hogue, 1971). The last published paper about Kelloggina species was from Lane \& d'Andretta (1956). The authors published the results of a regional survey, based on 227 specimens collected from few areas in the southeastern region of Brazil. Their survey result- ed in descriptions of 14 new species, including nine from Itatiaia, Rio de Janeiro (RJ), two from Alto Caparaó, Minas Gerais (MG), and three from São Paulo (SP) sites.

Comparing the species described by Lutz (1920) with Lane \& d'Andretta's (1956) is a difficult task. The delimitations of Lutz's species were clearly based on the immatures; in contrast, Lane \& d'Andretta's exclusive reliance on adults. Lane \& d'Andretta (1956) indicated further: "We had great difficult in the interpretation of his [Lutz] descriptions and, as we are not able to see his material, we feel that mistakes and possible synonyms may occur and that when a more extensive study can be made from bred material, some of our forms may be representatives of Lutz's species, specially those which he described from the immature stages." As stated by Hogue (1971), both studies focused on the same area of southeastern Brazil and there may be some overlapped species. Lutz (1920) provided useful descriptions of the immatures, which are richly illustrated, but did not provide the same treatment to adults, which are neither well described, nor well illustrated. On the other hand, Lane \& d'Andretta (1956) presented superficial descriptions of adults. They illustrate only general characteristics of male terminalia, which curiously are not described in the paper. 


\section{MATERIAL AND METHODS}

The combination of these two main studies makes the identification of Kelloggina adults difficult, especially without the direct comparison of type material.

Lane \& d'Andretta (1956) deposited all the holotypes and most paratypes at the Entomological Collection of Faculdade de Saúde Pública da Universidade de São Paulo (FSP-USP, SP, Brazil). Since the 1970's the FSP-USP collection has housed only Diptera of medical importance, with all the other specimens (including Blephariceridae) moved to the Diptera Collection of Museu de Zoologia, Universidade de São Paulo (MZSP, SP, Brazil) (Falaschi et al., 2018). These blepharicerid types are critical to understanding Lane \& d'Andretta's species and our study aims to investigate and illustrate this material.
We provide a catalogue with the 14 nominal species of Blephariceridae (Kelloggina) described by Lane \& d'Andretta (1956), for which the type-specimens are deposited at the Diptera Collection of the MZSP. We added distribution data and diagnoses for these 14 species with their respective discussions.

We include photographs for all holotypes. Images were taken with a digital Axiocam MRc5 camera connected to a Zeiss Discovery V20 stereomicroscope, using the software ZEISS AxioVs40 v. 4.8.2.0. Photographs were taken at sequential focal planes and then combined with the software Helicon Focus ${ }^{\circledR}$ version 4.2.9,

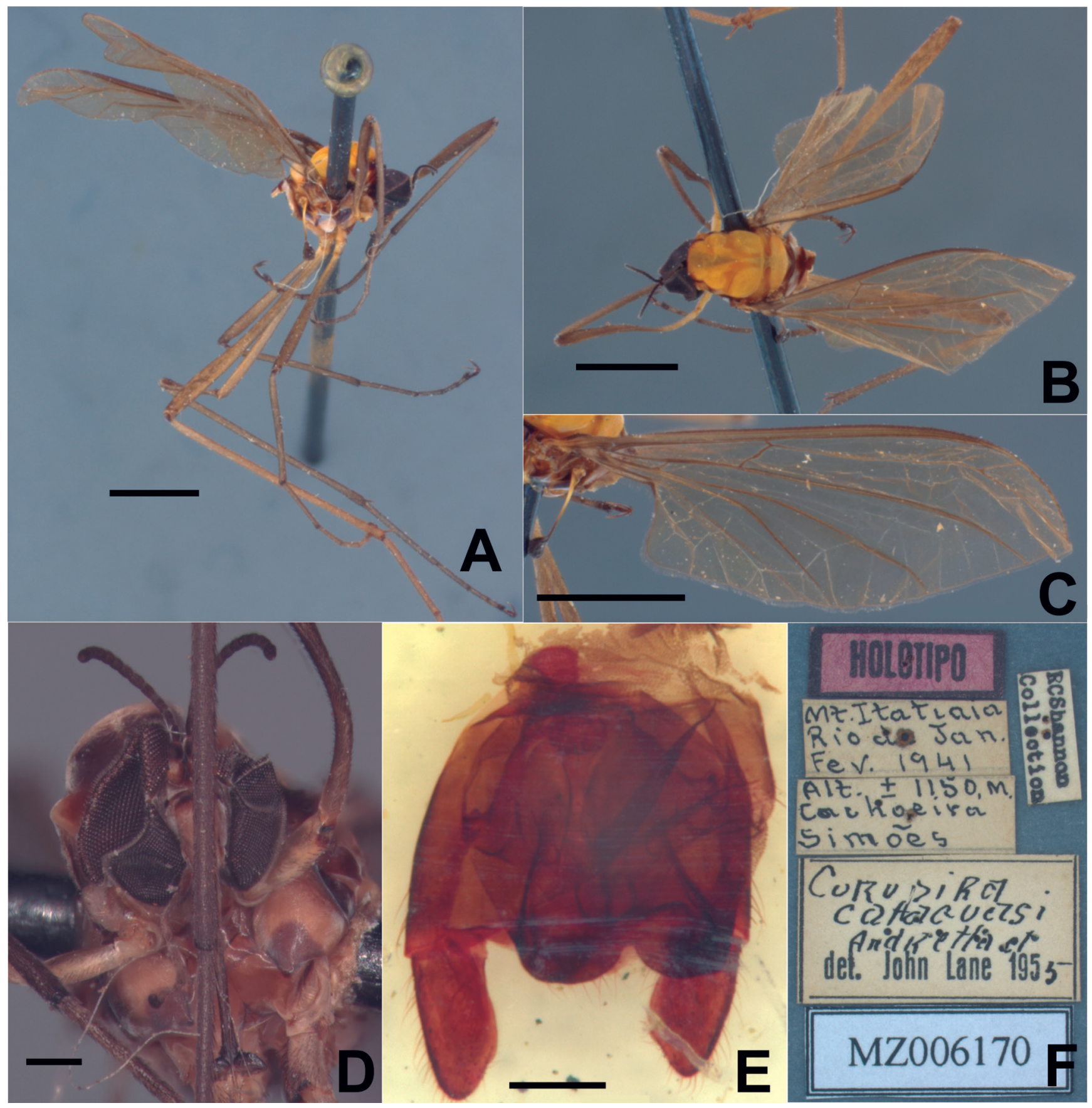

Figure 1. Holotype male of Kelloggina cataguasi Lane \& d'Andretta, 1956. (A) Habitus, lateral view; (B) Habitus, dorsal view; (C) Wing; (D) Head, frontal view; (E) Male terminalia; (F) Labels. Scale bars: A-C $=2 \mathrm{~mm} ; \mathrm{D}-\mathrm{E}=0.2 \mathrm{~mm}$. 
method $B$, to obtain high-resolution stacked images. When possible, photographs were taken from frontal, dorsal, and lateral views of the body, wings, and terminalia. Additionally, we include all label data for each specimen.

\section{RESULTS}

From the 171 types (138 males and 33 females) cited by the Lane \& d'Andretta (1956), 60 were deposited at MZSP, including male holotypes of 14 species and fe- males "allotypes" (paratypes) for seven species. Twentyeight paratypes ( 23 males and 5 females) were loaned to LHGA and unfortunately lost during the Museu Nacional, RJ, Brazil (MNRJ) fire, on 02 September 2018. A total of 83 paratypes ( 62 males and 21 females) were not located. According to Lane \& d'Andretta (1956) some paratypes were sent to the Natural History Museum (London, UK), Smithsonian National Museum of Natural History (Washington, USA), Coleção Entomológica do Instituto Oswaldo Cruz (Rio de Janeiro, Brazil), and Faculdade de Farmácia e Odontologia (São Paulo, Brazil) collections, but we were unable to examine this material.

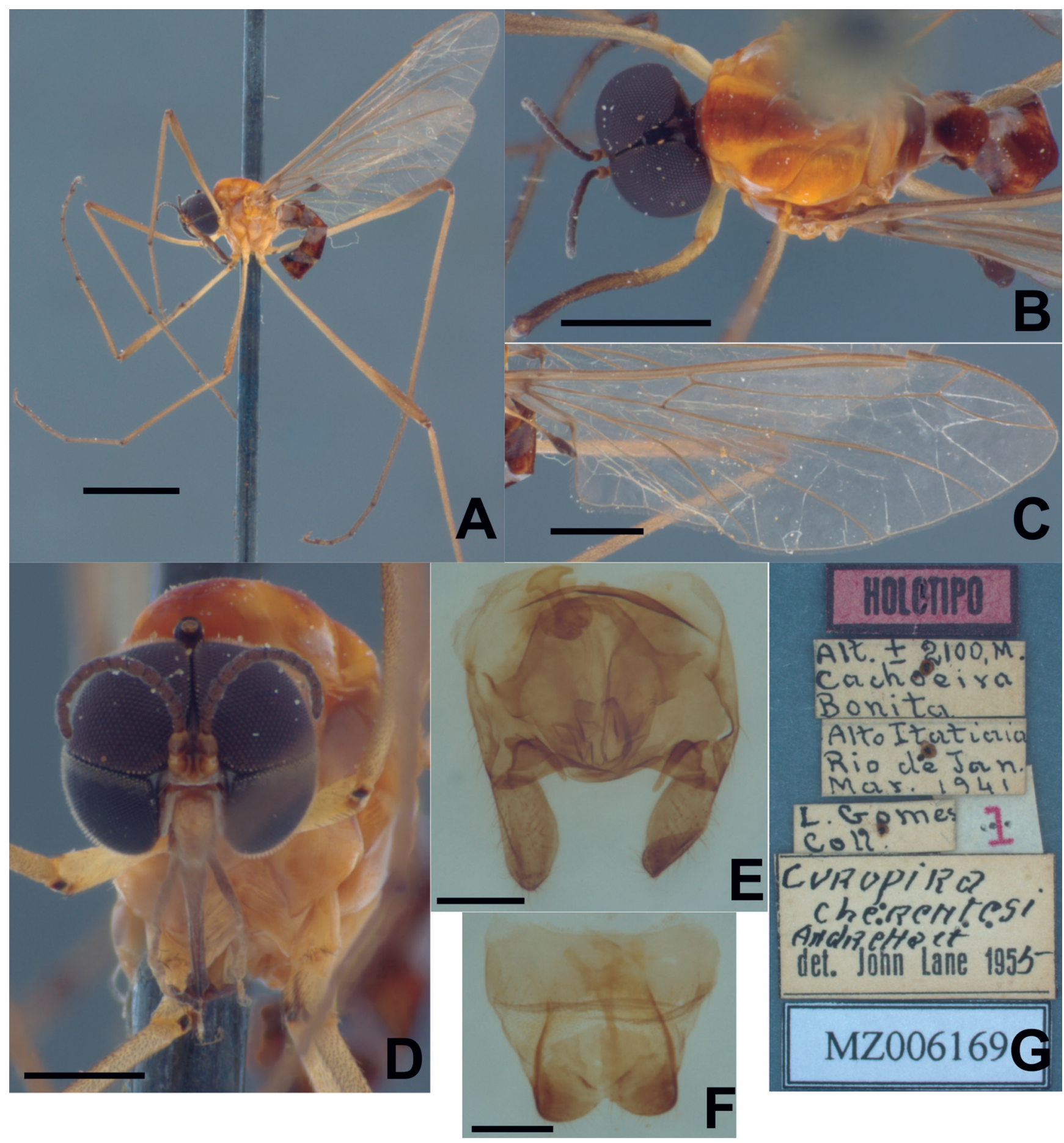

Figure 2. Holotype male of Kelloggina cherentesi Lane \& d'Andretta, 1956: (A) Habitus, lateral view; (B) Habitus, dorsal view; (C) Wing; (D) Head, frontal view; (E-F) Male terminalia; (G) Labels. Scale bars: $A=2 \mathrm{~mm} ; B-C=1 \mathrm{~mm} ; D=0.5 \mathrm{~mm} ; \mathrm{E}-\mathrm{F}=0.2 \mathrm{~mm}$. 
All holotypes are pinned and well preserved. The holotype abdomens were dissected, with terminalia mounted on a slide.

\section{Family Blephariceridae Loew, 1861 Subfamily Blepharicerinae Loew Tribe Paltostomatini Bezzi, 1913 Genus Kelloggina Williston, 1907}

Snowia Williston, 1893: 119 (preoccupied). Type-species, Snowia rufescens Williston (original designation).

Sackeniella Williston, 1896: 270 (nom. nov. for Snowia Williston, but preoccupied).

Kelloggina Williston, 1907: 1 (nom. nov. for Snowia Williston). Curupira Osten-Sacken, 1895 (preoccupied and junior synonym). Type-species, Paltostoma torrentium Müller (original designation).
Dimorphotarsa Lutz, 1920: 29 (junior synonym). Typespecies: Dimorphotarsa fascibranchia (subsequent designation Alexander, 1958: 820).

Dimorphotaenia Lutz, 1920: 26 (German translation) (lapsus for Dimorphotarsa Lutz).

\section{Kelloggina cataguasi Lane \& d'Andretta, 1956}

(Fig. 1)

Lane \& d'Andretta (1956: 181, fig. 2). Hogue (1971: 4).

Types in MZSP: HOLOTYPE (Fig. 1): $1 \sigma^{\pi}$ (\#MZ006170) from Brazil, RJ, Itatiaia, Cachoeira Simões, 1,150 m a.s.l., II/1941. PARATYPE: 1 (allotype), same data of holotype.

Diagnosis: Male (Fig. 1): General coloration yellow. Head: Front brown and clypeus yellow. Eyes broad-
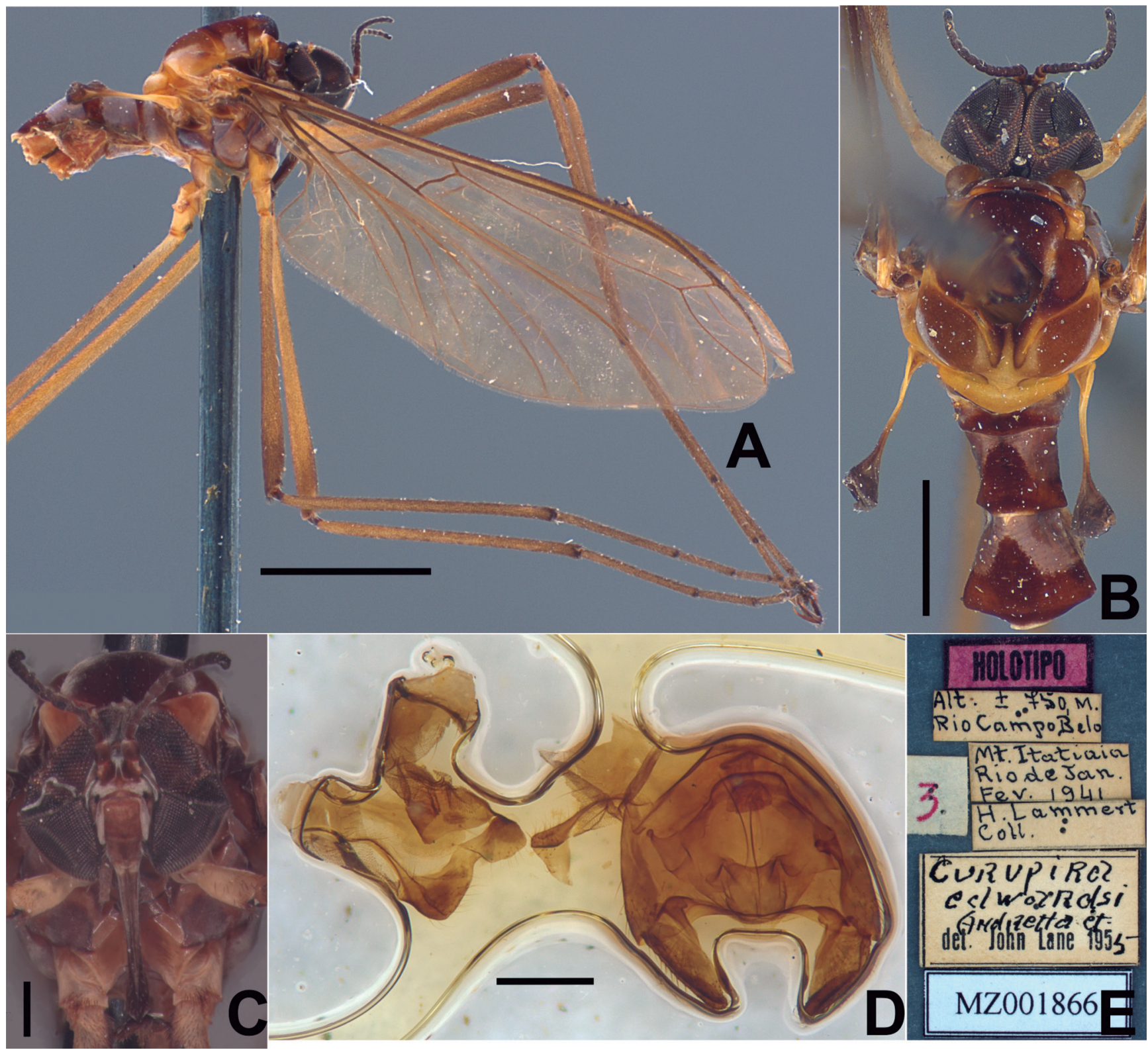

Figure 3. Holotype male of Kelloggina edwardsi Lane \& d'Andretta, 1956: (A) Habitus, lateral view; (B) Habitus, dorsal view; (C) Head, frontal view; (D) Male terminalia; (E) Labels. Scale bars: $A=2 \mathrm{~mm} ; B=1 \mathrm{~mm} ; C-D=0.2 \mathrm{~mm}$. 
ly contiguous and united above; upper portion quite larger than the lower one. Antenna with 14 segments, scape brown, pedicel and flagellum black. Proboscis slightly longer than head. Palpus with four segments, three basal segments yellow, the last one black. Thorax: Pronotum dark brown. Scutum yellow, with 1+1 antero-lateral dark brown spots continuous to the prono- tum. Scutellum yellow. Pleura dark brown with large yellow marks. Legs: Coxae and trochanters yellow, femora yellow at base and darker apically, tibiae and tarsi dark brown. Hind tibia with two spurs. Hind last tarsal segment with a bristly basal enlargement. Wing hyaline, with costal cell yellowish. Vein m-m present and complete.

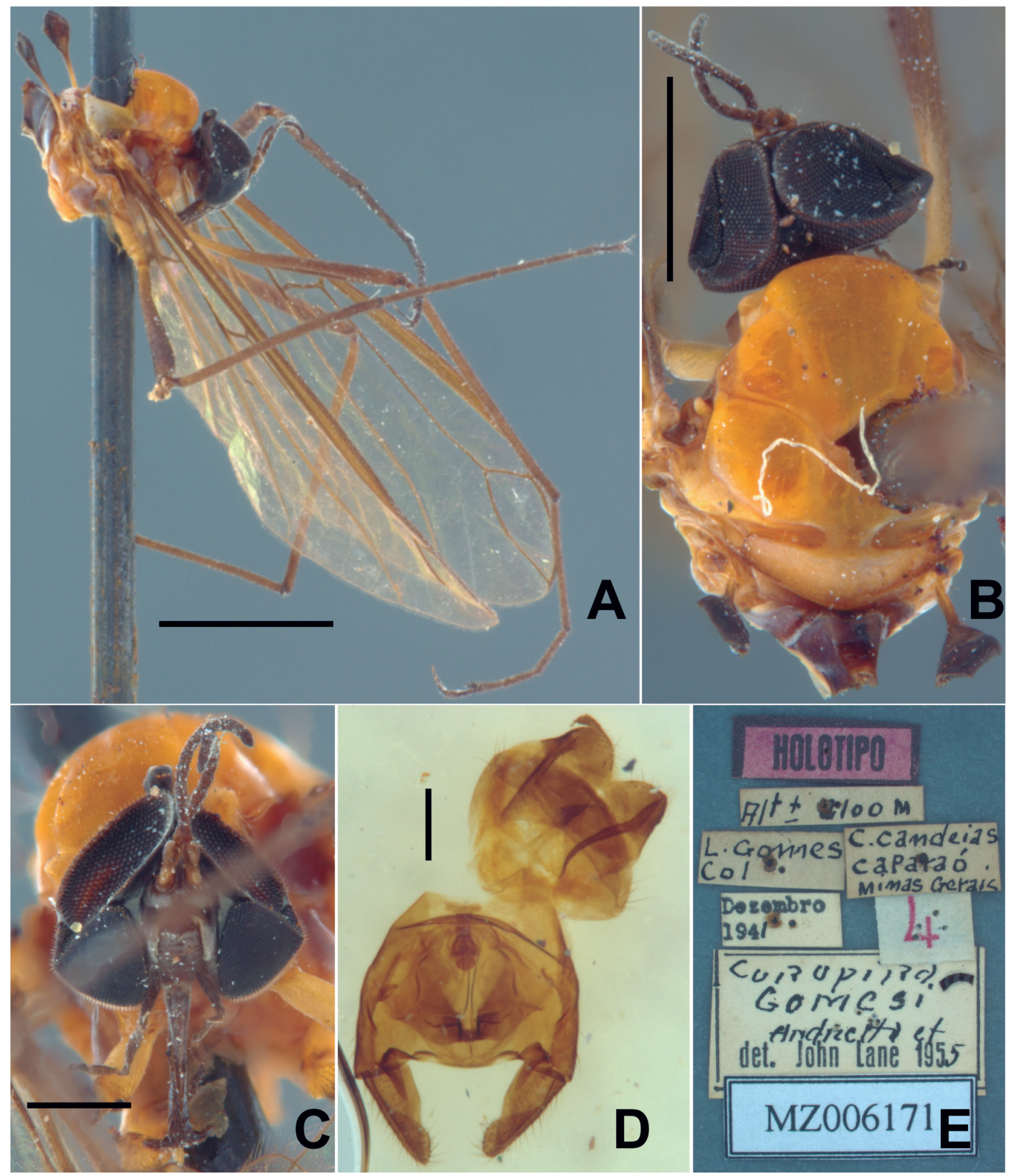

Figure 4. Holotype male of Kelloggina gomesi Lane \& d'Andretta, 1956: (A) Habitus, lateral view; (B) Habitus, dorsal view; (C) Head, frontal view; (D) Male terminalia; (E) Labels. Scale bars: $A=2 \mathrm{~mm} ; B=1 \mathrm{~mm} ; C=0.5 \mathrm{~mm} ; D=0.2 \mathrm{~mm}$. 
Distribution: BRAZIL: RJ (Itatiaia).

Remarks: Lane \& d'Andretta (1956) listed an additional four paratypes, $2 \sigma^{\prime \prime}$ and $2 \%$, but they were not examined.

\section{Kelloggina cherentesi Lane \& d'Andretta, 1956}

(Fig. 2)

Lane \& d'Andretta (1956: 183, fig. 3). Hogue (1971: 4).

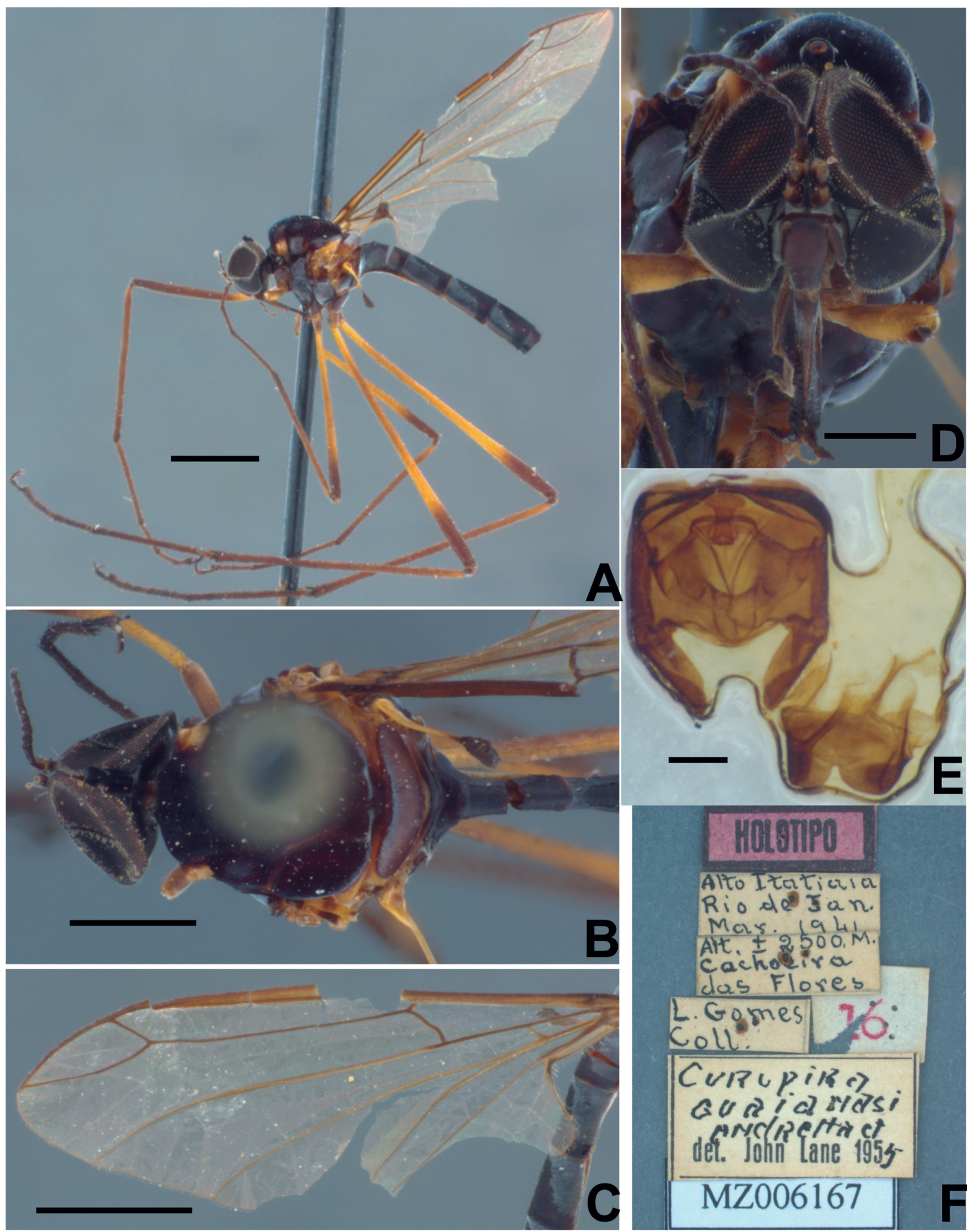

Figure 5. Holotype male of Kelloggina guaianasi Lane \& d'Andretta, 1956: (A) Habitus, lateral view; (B) Habitus, dorsal view; (C) Wing; (D) Head, frontal view; (E) Male terminalia; (F) Labels. Scale bars: $A, C=2 \mathrm{~mm} ; B=1 \mathrm{~mm} ; D=0.5 \mathrm{~mm} ; E=0.2 \mathrm{~mm}$. 


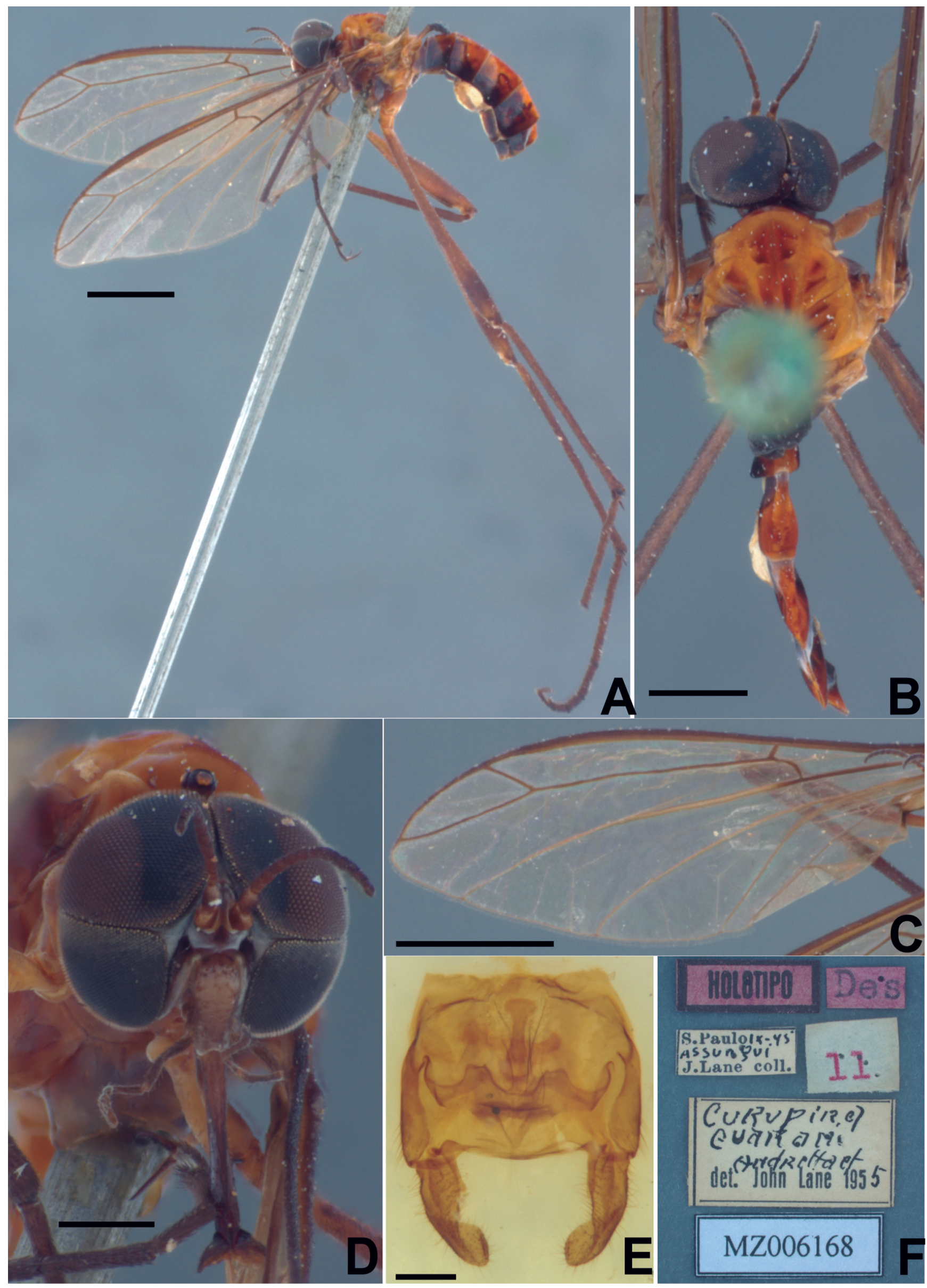

Figure 6. Holotype male of Kelloggina guarani Lane \& d'Andretta, 1956: (A) Habitus, lateral view; (B) Habitus, dorsal view; (C) Wing; (D) Head, frontal view; (E) Male terminalia; (F) Labels. Scale bars: $A, C=2 \mathrm{~mm} ; B=1 \mathrm{~mm} ; D=0.5 \mathrm{~mm} ; E=0.2 \mathrm{~mm}$. 
Types in MZSP: HOLOTYPE (Fig. 2): $1 \sigma^{\pi}$ (\#MZ006169) from Brazil, RJ, Itatiaia, Cachoeira Bonita, 2,100 m a.s.l., III/1941, Lério Gomes coll. PARATYPE: 1 \& (allotype), same data of holotype.

Diagnosis: Male (Fig. 2): General coloration yellow. Head: Front and clypeus brown. Eyes broadly contiguous and united above; upper portion quite larger than the lower one. Antenna with 14 segments, scape yellow, pedicel and flagellum brown. Proboscis distinctly longer than head. Palpus with four black segments. Thorax: Pronotum yellow. Scutum yellow, with a broad median and 1+1 lateral brown stripes. Scutellum yellow. Legs: Coxae and trochanters yellow, femora yellow at base and darker apically, tibiae and tarsi dark brown. Hind tibia with two spurs. Hind last tarsal segment with a bristly basal enlargement. Wing hyaline. Vein m-m absent.

Distribution: BRAZIL: RJ (Itatiaia).

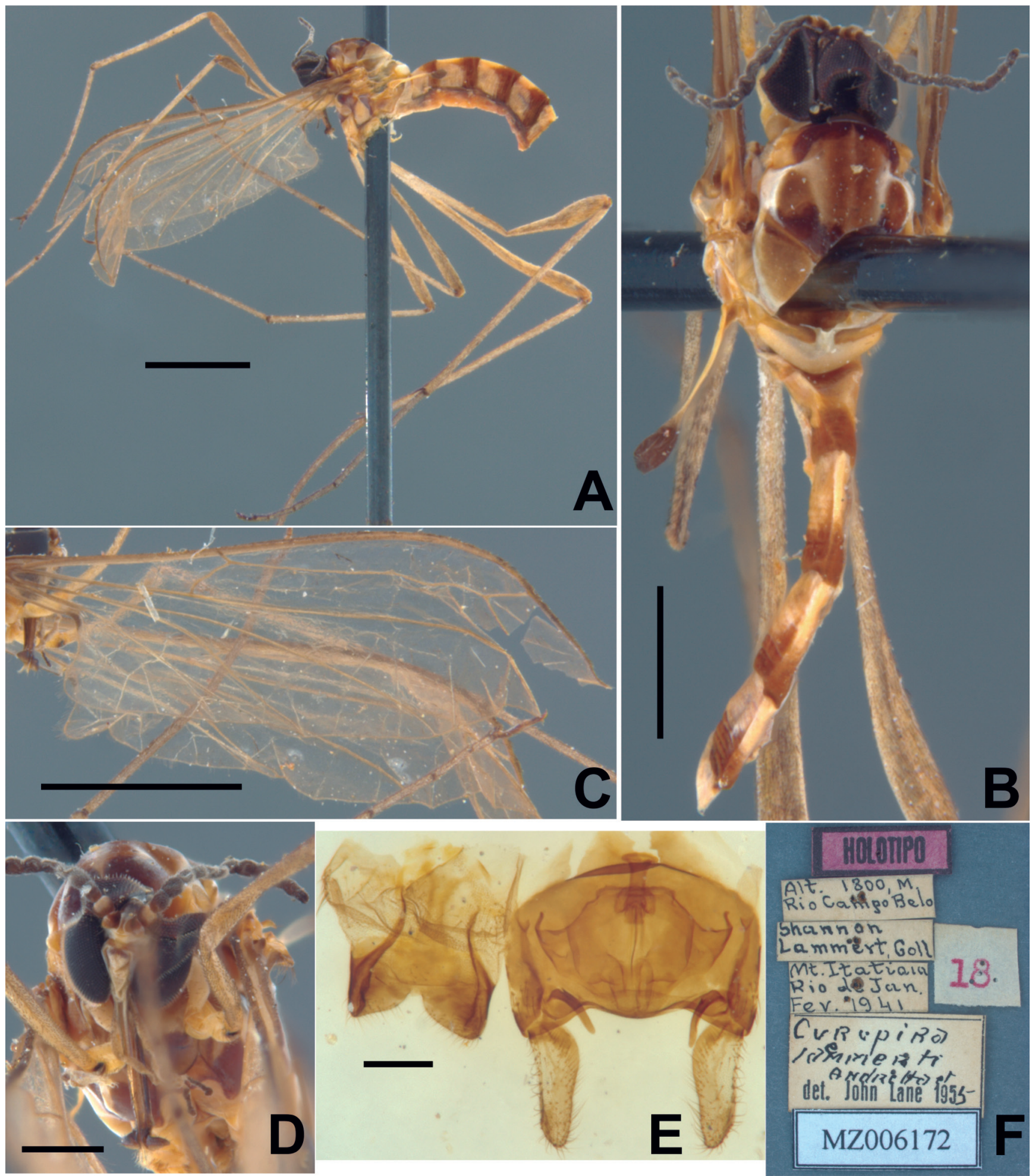

Figure 7. Holotype male of Kelloggina laemmerti Lane \& d'Andretta, 1956: (A) Habitus, lateral view; (B) Habitus, dorsal view; (C) Wing; (D) Head, frontal view; (E) Male terminalia; (F) Labels. Scale bars: $A, C=2 \mathrm{~mm} ; B=1 \mathrm{~mm} ; D=0.5 \mathrm{~mm} ; E=0.2 \mathrm{~mm}$. 
Remarks: Lane \& d'Andretta (1956) listed an additional three paratypes, $2 \sigma^{\prime \prime}$ and 19 . One male paratype was lost during the MNRJ fire. The other two were not examined.

\section{Kelloggina edwardsi Lane \& d'Andretta, 1956 (Fig. 3)}

Lane \& d'Andretta (1956: 184, fig. 4). Hogue (1971: 4).

Types in MZSP: HOLOTYPE (Fig. 3): $1 \sigma^{\pi}$ (\#MZ001866), from Brazil RJ, Itatiaia, Rio Campo Bello, 750 m a.s.l., II/1941, H. Laemmert coll.
Diagnosis: Male (Fig. 3): General coloration brown. Head: Front and clypeus dark brown. Eyes broadly contiguous and united above; upper portion quite larger than the lower one. Antenna with 14 segments, scape brown, pedicel and flagellum black. Proboscis slightly longer than head. Palpus with four segments, three basal segments brown, the last one black. Thorax: Pronotum dark brown. Scutum light brown, with $1+1$ thin antero-lateral yellow stripes. Scutellum yellow. Pleura dark brown with large yellow marks. Legs: Coxae and trochanters yellow, femora yellow at base and darker apically, tibiae and tarsi dark brown. Hind tibia with two spurs. Hind last tarsal segment with a bristly basal enlargement.
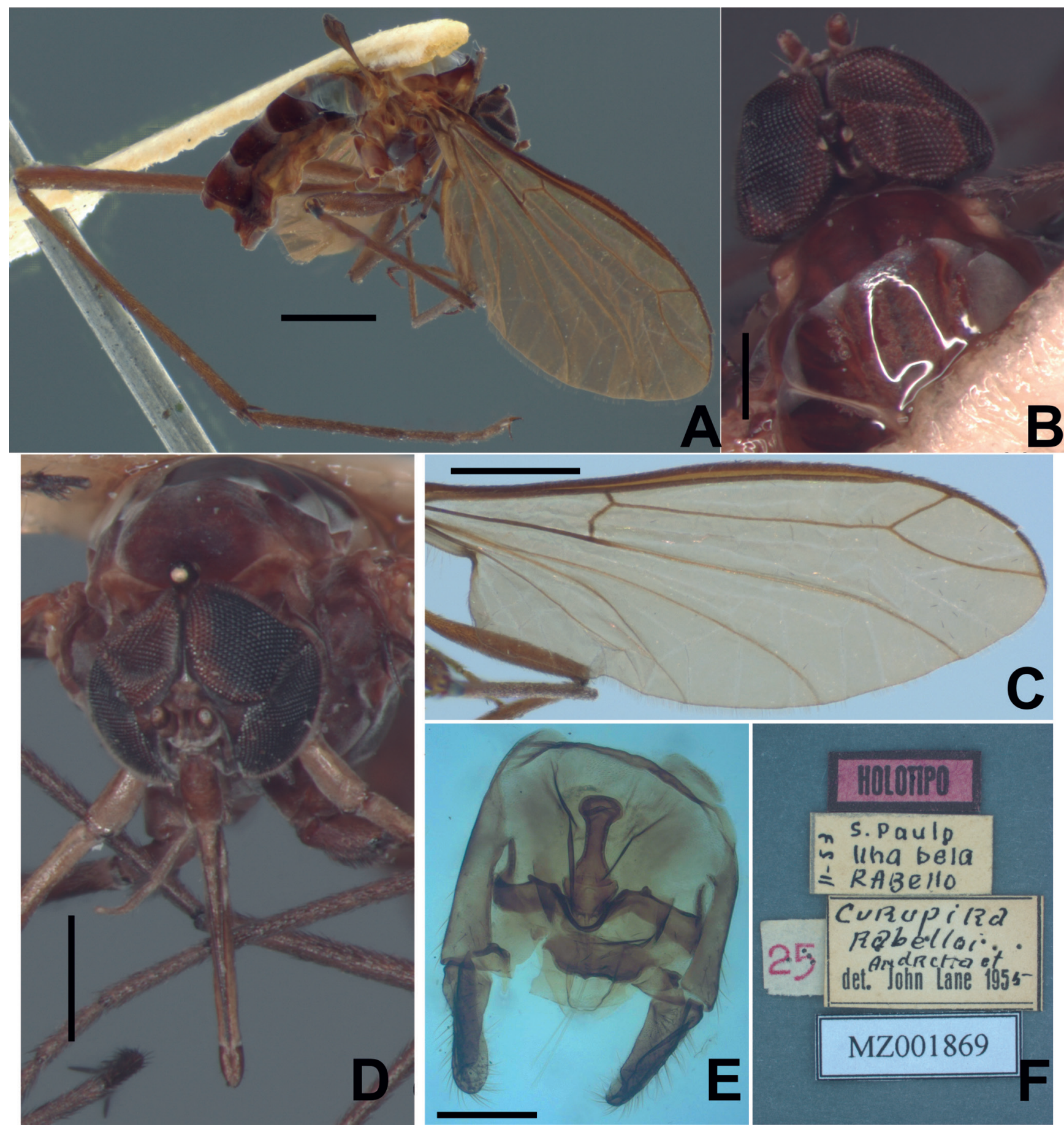

Figure 8. Holotype male of Kelloggina rabelloi Lane \& d'Andretta, 1956: (A) Habitus, lateral view; (B) Habitus, dorsal view; (C) Wing; (D) Head, frontal view; (E) Male terminalia; (F) Labels. Scale bars: $A, C=1 \mathrm{~mm} ; B, E=0.2 \mathrm{~mm} ; D=0.5 \mathrm{~mm}$. 
Wing hyaline, with costal cell yellowish. Vein m-m present and complete.

Distribution: BRAZIL: RJ (Itatiaia).

Remarks: Female unknown.

\section{Kelloggina gomesi Lane \& d'Andretta, 1956}

(Fig. 4)

Lane \& d'Andretta (1956: 186, fig. 5). Hogue (1971: 4): Kelloggina gomezi [typographic error].

Types in MZSP: HOLOTYPE (Fig. 4): $1 \sigma^{\top}$ (\#MZ006171) from Brazil, MG, Alto Caparaó, Córrego Candeias, 2,100 m a.s.l., XII/1941, Lério Gomes coll. PARATYPES: 1 \% (allotype) from Brazil, MG, Alto Caparaó, Córrego Macieira, 2,200 m a.s.l., XI/1941, Lério Gomes coll.; 1 ơ from Brazil, MG, Alto Caparaó, Córrego Candeias, 2,100 m a.s.I., XII/1941, Lério Gomes coll; 3 ơ from Brazil, MG, Alto Caparaó, Córrego Macieira, 2,200 m a.s.l., XI/1941, Lério Gomes coll.; $13 \sigma^{7}$ from Brazil, MG, Alto Caparaó, Rio Preto, 2,400 m a.s.l., XII/1941, Lério Gomes coll.

Diagnosis: Male (Fig. 4): General coloration yellow. Head: Front and clypeus dark brown. Eyes broadly contiguous and united above; upper portion quite larger than the lower one. Antenna with 14 segments, scape and pedicel brown, flagellum black. Proboscis slightly longer than head. Palpus with four black segments. Thorax: Pronotum yellow. Scutum yellow. Scutellum yellow. Pleura yellow with light brown areas. Legs: Coxae and trochanters yellow, femora yellow at base and darker apically, tibiae and tarsi dark brown. Hind tibia with two spurs. Hind last tarsal segment with a bristly basal enlargement. Wing hyaline, with costal cell yellowish. Vein m-m present and complete.

Distribution: BRAZIL: MG (Alto Caparaó).

Remarks: Lane \& d'Andretta (1956) listed an additional $11 \sigma^{x}$ and $11 \%$ paratypes. $5 \sigma^{x}$ and $2 \%$ paratype were lost during the MNRJ fire. The other $6 \sigma^{\prime}$ and 9 were not examined.

\section{Kelloggina guaianasi Lane \& d'Andretta, 1956} (Fig. 5)

Lane \& d'Andretta (1956: 187, fig. 6) [also Kelloggina guayanasi: 187, typographic error]. Hogue (1971: 5).

Types in MZSP: HOLOTYPE (Fig. 5): $1 \sigma^{7}$ (\#MZ006167) from Brazil, RJ, Itatiaia, Cachoeira das Flores, 2,500 m a.s.l., III/1941, Lério Gomes coll. PARATYPE: 1 ơ from Brazil, RJ, Itatiaia, Cachoeira Pinheiros, 2,000 m a.s.l., Ill/1941, Lério Gomes coll.

Diagnosis: Male (Fig. 5): General coloration black. Head: Front and clypeus dark brown. Eyes broadly con- tiguous and united above; upper portion quite larger than the lower one. Antenna with 14 segments, scape, pedicel, and flagellum black. Proboscis slightly longer than head. Palpus with four black segments. Thorax: Pronotum black. Scutum black. Scutellum black. Pleura black with large yellow marks. Legs: Coxae and trochanters dark brown, femora yellow at base and dark brown apically, tibiae and tarsi dark brown. Hind tibia with two spurs. Hind last tarsal segment with a bristly basal enlargement. Wing hyaline, with costal cell yellowish. Vein $\mathrm{m}-\mathrm{m}$ present and complete.

\section{Distribution: BRAZIL: RJ (Itatiaia).}

Remarks: Female unknown. Lane \& d'Andretta (1956) listed an additional $5 \sigma^{7}$ paratypes. One male paratype was lost during the MNRJ fire. The other four were not examined.

\section{Kelloggina guarani Lane \& d'Andretta, 1956}

(Fig. 6)

Lane \& d'Andretta (1956: 188, fig. 7). Hogue (1971: 5).

Types in MZSP: HOLOTYPE (Fig. 6): 1 o' (\#MZ006168) from Brazil, SP, Juquiá, Salto do Assungui, $100 \mathrm{~m}$ a.s.l., IX/1945, John Lane coll. PARATYPES: 1 @ (allotype) and $130^{2}$, same data of holotype.

Diagnosis: Male (Fig. 6): General coloration yellow. Head: Front and clypeus dark brown. Eyes broadly contiguous and united above; upper portion quite larger than the lower one. Antenna with 14 segments, scape, pedicel, and flagellum brown. Proboscis slightly longer than head. Palpus with four black segments. Thorax: Pronotum orange. Scutum orange, with a broad median and $1+1$ lateral brown stripes. Scutellum orange. Pleura brown with large yellow marks. Legs: Coxae and trochanters yellow, femora brown, mid and hind femora with a darker area apically, tibiae and tarsi dark brown. Hind tibia with two spurs. Hind last tarsal segment with a bristly basal enlargement. Wing hyaline, with costal cell yellowish. Vein m-m absent.

Distribution: BRAZIL: SP (Juquiá).

Remarks: Lane \& d'Andretta (1956) listed an additional $28 \sigma^{7}$ and $1 \%$ paratypes. Five male paratypes were lost during the MNRJ fire. The other $23 \sigma^{x}$ and $1 \%$ were not examined.

\section{Kelloggina laemmerti Lane \& d'Andretta, 1956}

(Fig. 7)

Lane \& d'Andretta (1956: 190, fig. 8). Hogue (1971: 5).

Types in MZSP: HOLOTYPE (Fig. 7): $1 \sigma^{7}$ (\#MZ006172) from Brazil, RJ, Itatiaia, Rio Campo Belo, 1,800 m a.s.l., 
II/1941, Raymond C. Shannon \& Hugo Laemmert coll. PARATYPE: $10^{n}$, same data of holotype.

Diagnosis: Male (Fig. 7): General coloration yellow. Head: Front brown and clypeus yellow. Eyes broadly contiguous and narrowly separated above; upper portion quite larger than the lower one. Antenna with 14 segments, scape and pedicel brown, flagellum black. Proboscis distinctly longer than head. Palpus with four black segments. Thorax: Pronotum yellow. Scutum yel-
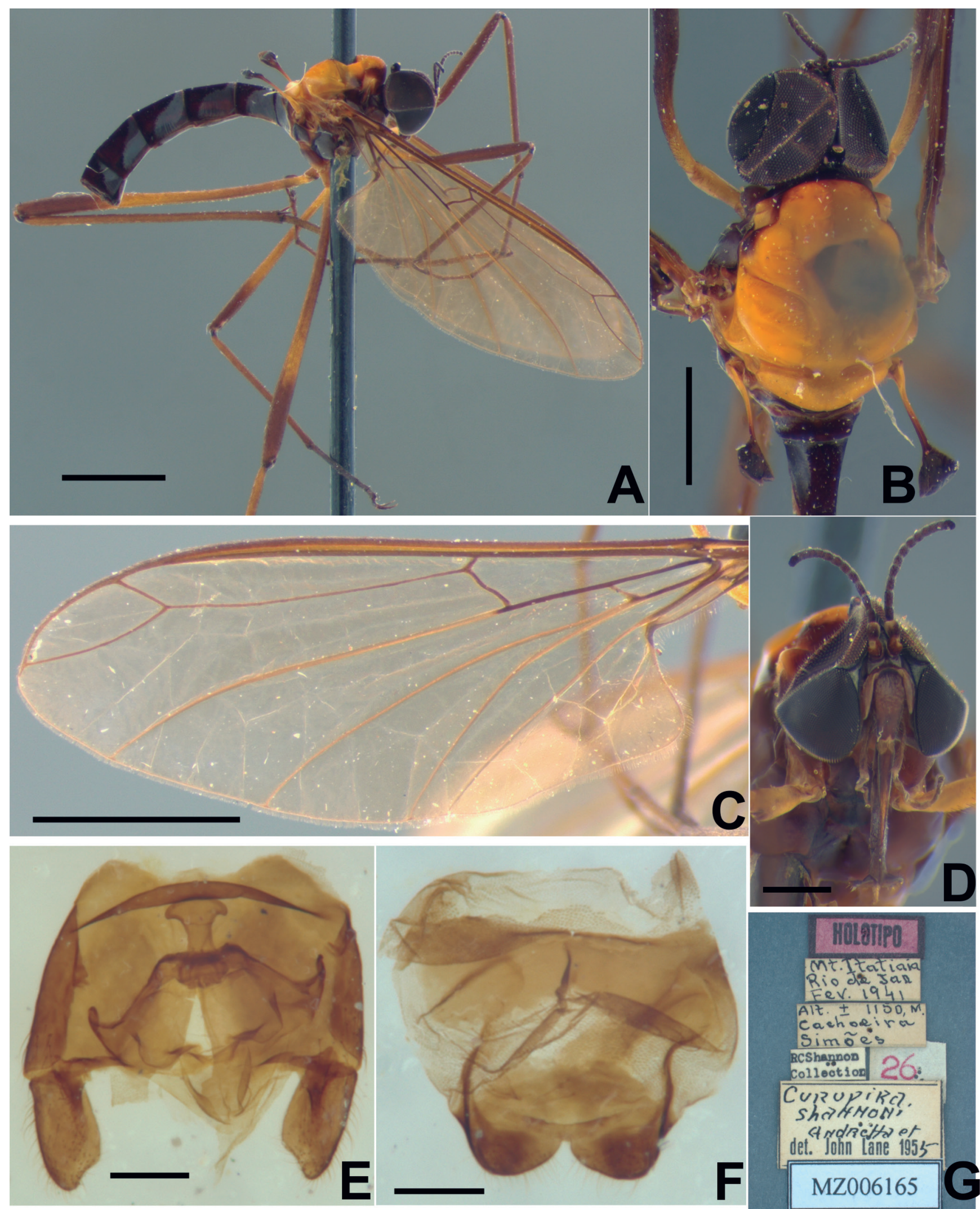

Figure 9. Holotype male of Kelloggina shannoni Lane \& d'Andretta, 1956: (A) Habitus, lateral view; (B) Habitus, dorsal view; (C) Wing; (D) Head, frontal view; (E-F) Male terminalia; (G) Labels. Scale bars: $A, C=2 \mathrm{~mm} ; B=1 \mathrm{~mm} ; D=0.5 \mathrm{~mm} ; \mathrm{E}-\mathrm{F}=0.2 \mathrm{~mm}$. 
low, with a broad median and $1+1$ lateral brown stripes. Scutellum yellow. Pleura yellow with light brown areas. Legs: Coxae, trochanters, femora, tibiae, and tarsi yellow.
Hind tibia with two spurs. Hind last tarsal segment with a bristly basal enlargement. Wing hyaline, with costal cell yellowish. Vein $\mathrm{m}$-m absent, only a stump on $\mathrm{M}_{4}$ vein.

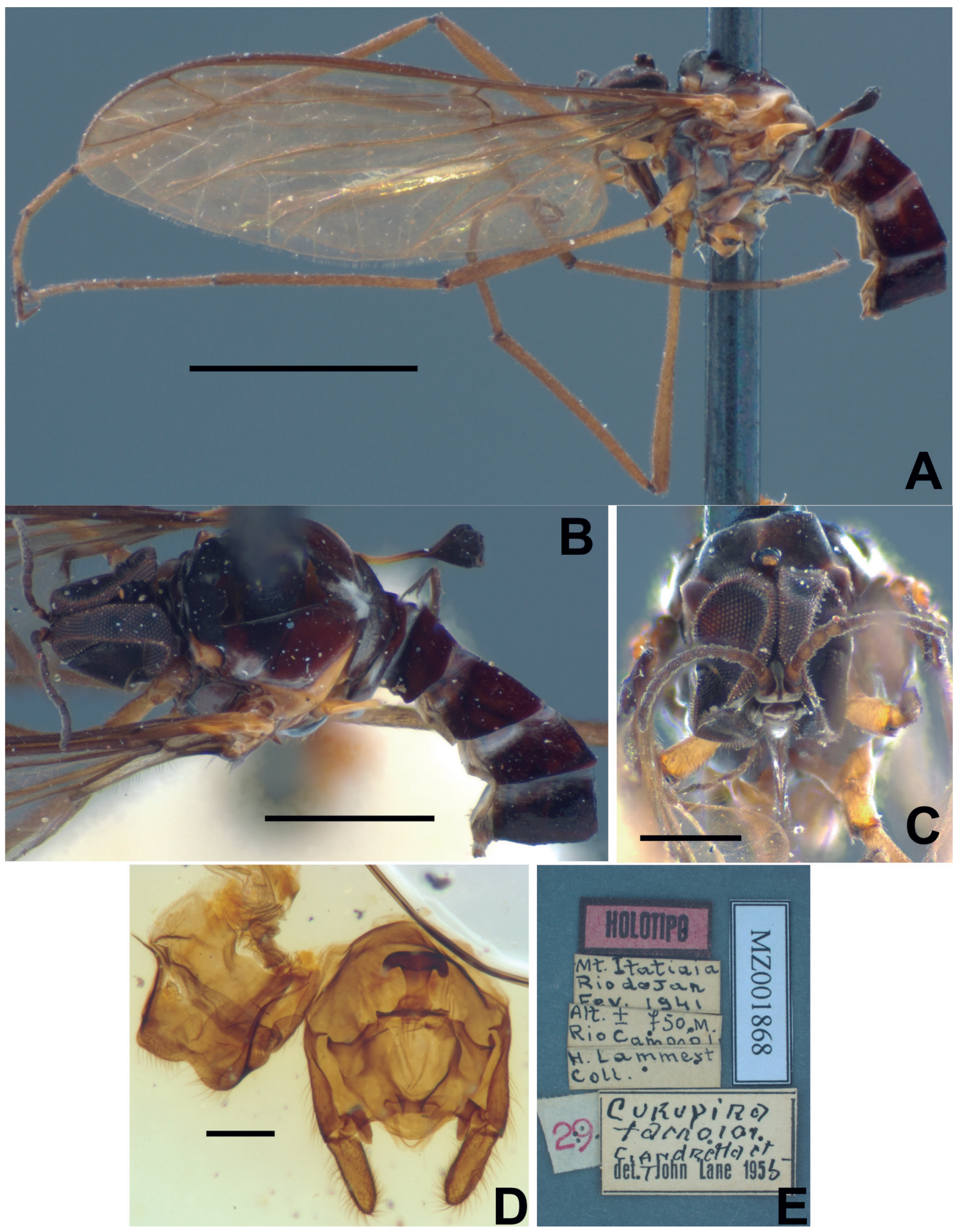

Figure 10. Holotype male of Kelloggina tamoioi Lane \& d'Andretta, 1956: (A) Habitus, lateral view; (B) Habitus, dorsal view; (C) Head, frontal view; (D) Male terminalia; (E) Labels. Scale bars: $A=2 \mathrm{~mm} ; B=1 \mathrm{~mm} ; C=0.5 \mathrm{~mm} ; D=0.2 \mathrm{~mm}$. 
Distribution: BRAZIL: RJ (Itatiaia).

Remarks: Female unknown. Lane \& d'Andretta (1956) listed an additional $12 \sigma^{\prime \prime}$ paratypes. Four male paratypes were lost during the MNRJ fire. The other eight were not examined.

\section{Kelloggina rabelloi Lane \& d'Andretta, 1956 (Fig. 8)}

Lane \& d'Andretta (1956: 195, fig. 11). Hogue (1971: 5).
Types in MZSP: HOLOTYPE (Fig. 8): $1 \sigma^{7}$ (\#MZ001869) from Brazil, SP, Ilhabela, 300 m a.s.l., II/1953, E.X. Rabello coll.

Diagnosis: Male (Fig. 8): General coloration brown. Head: Front and clypeus dark brown. Eyes broadly contiguous and narrowly separated above; upper portion slightly smaller than the lower one. Antenna with scape and pedicel black, holotype without flagellum. Proboscis distinctly longer than head. Palpus with four black segments. Thorax: Pronotum dark brown. Scutum dark brown, with 1+1 thin antero-lateral yellow stripes. Pleura brown with large yellow marks. Legs: Coxae and

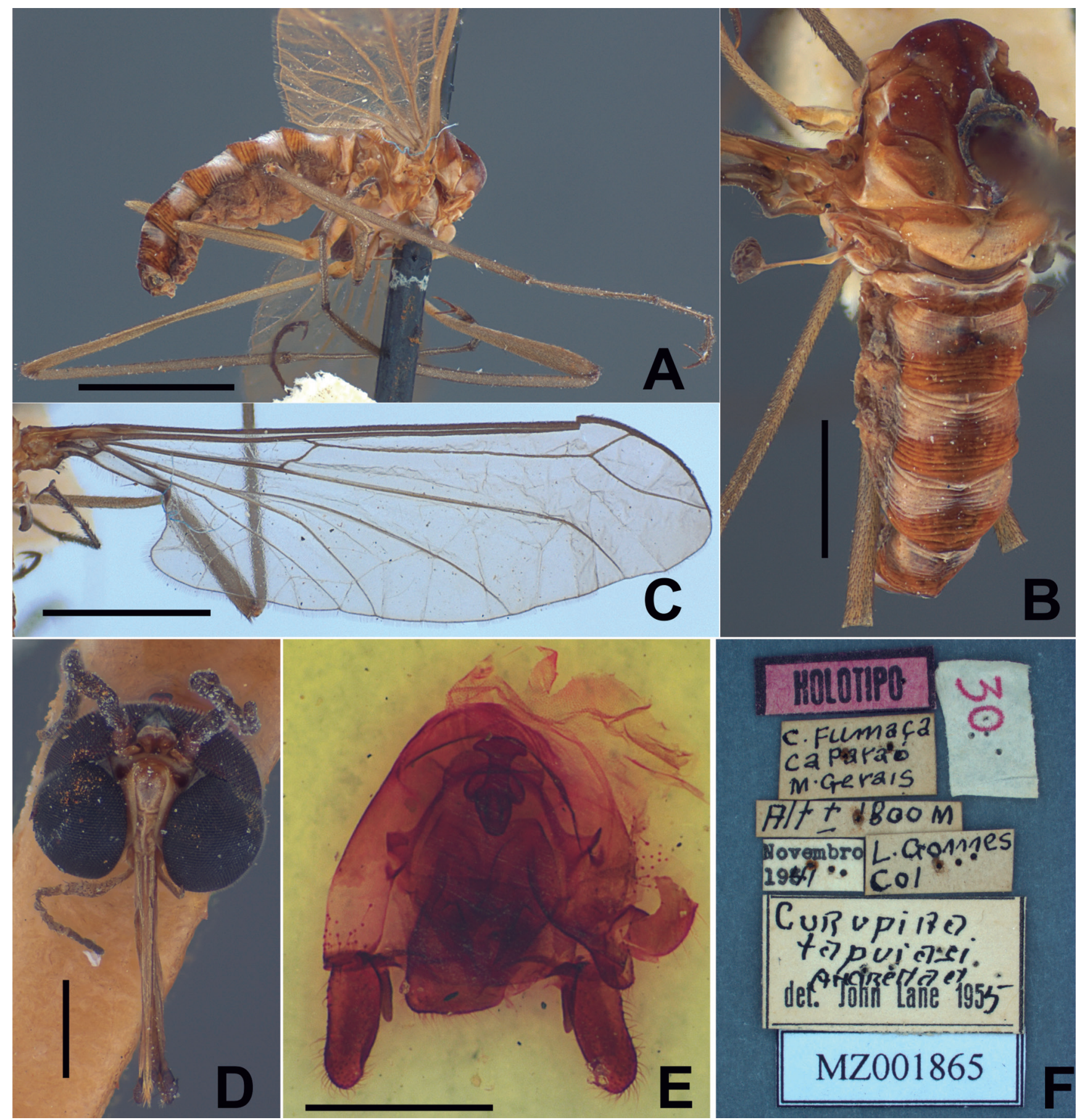

Figure 11. Holotype male of Kelloggina tapuiasi Lane \& d'Andretta, 1956: (A) Habitus, lateral view; (B) Habitus, dorsal view; (C) Wing; (D) Head, frontal view; (E) Male terminalia; (F) Labels. Scale bars: $A, C=2 \mathrm{~mm} ; B=1 \mathrm{~mm} ; D-E=0.5 \mathrm{~mm}$. 
trochanters yellow. Femora, tibiae, and tarsi dark brown. Hind tibia with two spurs. Hind last tarsal segment with a bristly basal enlargement. Wing smoky, with costal cell yellowish. Vein m-m absent.

Distribution: BRAZIL: SP (Ilhabela).

Remarks: Female unknown.

\section{Kelloggina shannoni Lane \& d'Andretta, 1956} (Fig. 9)

Lane \& d'Andretta (1956: 195, fig. 12). Hogue (1971: 6).

Types in MZSP: HOLOTYPE (Fig. 9): $10^{\pi}$ (\#MZ006165) from Brazil, RJ, Itatiaia, Cachoeira Simões, 1,150 m a.s.l., II/1941, Raymond C. Shannon coll. PARATYPES: 1 (allotype) from Brazil, RJ, Itatiaia, Cachoeira Bonita, 2,100 m a.s.l., II/1941; 6 ơ from Brazil, RJ, Itatiaia, Cachoeira Simões, 1,150 m, II/1941, Raymond C. Shannon coll; 1 ơ from Brazil, SP, Salesópolis, Boracéia (Estação Biológica), 1948.

Diagnosis: Male (Fig. 9): General coloration yellow. Head: Front and clypeus dark brown. Eyes broadly contiguous and united above; upper portion quite larger than the lower one. Antenna with 14 segments, scape and pedicel brown, flagellum black. Proboscis slightly longer than head. Palpus with four black segments. Thorax: Pronotum dark brown. Scutum yellow, with 1+1 antero-lateral dark brown spots continuous to the pronotum. Scutellum yellow. Pleura dark brown with large yellow marks. Legs: Coxae dark brown, trochanters yellow, femora and tibiae yellow at base and darker apically, tarsi dark brown. Hind tibia with two spurs. Hind last tarsal segment with a bristly basal enlargement. Wing hyaline, with costal cell yellowish. Vein m-m present and complete.

Distribution: BRAZIL: RJ (Itatiaia), SP (Salesópolis, Santo Antônio do Pinhal).

Remarks: Lane \& d'Andretta (1956) listed an additional $17 \sigma^{7}$ and $2 \%$ paratypes. Five male and one female paratypes were lost during the MNRJ fire. The other $120^{\prime}$ and 1 \& were not examined. Lane \& d'Andretta (1956) cited paratypes from: "Campos do Jordão, Eugênio Lefévre (1,200 m. alt.), ii.1953 (Travassos, col.)", but Eugênio Lefevre train station belongs to the Santo Antônio do Pinhal municipality and not to Campos do Jordão municipality.

\section{Kelloggina tamoioi Lane \& d'Andretta, 1956} (Fig. 10)

Lane \& d'Andretta (1956: 198, fig. 13). Hogue (1971: 6).

Types in MZSP: HOLOTYPE (Fig. 10): $1 \sigma^{\pi}$ (MZ001868) from Brazil, RJ, Itatiaia, Rio Campo Belo, $750 \mathrm{~m}$ a.s.l., II/1941, Hugo Laemmert coll.
Diagnosis: Male (Fig. 10): General coloration black. Head: Front and clypeus dark brown. Eyes broadly contiguous and united above; upper portion quite larger than the lower one. Antenna with 14 segments, scape, pedicel, and flagellum black. Proboscis slightly longer than head. Palpus with four black segments. Thorax: Pronotum black. Scutum black, with three pruinose stripes in the middle. Scutellum black. Pleura dark brown with large yellow marks. Legs: Coxae and trochanters yellow, femora yellow at base and darker apically, tibiae and tarsi light brown. Hind tibia with two spurs. Hind last tarsal segment with a bristly basal enlargement. Wing hyaline, with costal cell yellowish. Vein m-m absent.

\section{Distribution: BRAZIL: RJ (Itatiaia).}

Remarks: Female unknown. Lane \& d'Andretta (1956) listed an additional $3 \sigma^{x}$ paratypes, but they were not examined.

\section{Kelloggina tapuiasi Lane \& d'Andretta, 1956} (Fig. 11)

Lane \& d'Andretta (1956: 198, fig. 14). Hogue (1971: 6).

Types in MZSP: HOLOTYPE (Fig. 11): $1 \sigma^{x}$ (\#MZ001865) from Brazil, MG, Alto Caparaó, Cachoeira da Fumaça, 1,800 m a.s.l., XI/1941, Lério Gomes coll. PARATYPE: 1 \& (allotype) from Brazil, MG, Alto Caparaó, Rio Preto, 1,880 m a.s.l., XI/1941, Lério Gomes coll.

Diagnosis: Male (Fig. 11): General coloration yellow. Head: Front brown and clypeus yellow. Eyes broadly contiguous and united above; upper portion quite larger than the lower one. Antenna with 14 segments, scape brown, pedicel and flagellum black. Proboscis distinctly longer than head. Palpus with four black segments. Thorax: Pronotum light brown. Scutum light brown, with a broad median and 1+1 lateral brown stripes. Scutellum yellow. Pleura yellow. Legs: Coxae, trochanters, and femora yellow, tibiae and tarsi light brown. Hind tibia with two spurs. Hind last tarsal segment with a bristly basal enlargement. Wing hyaline, with costal cell yellowish. Vein $\mathrm{m}$-m absent, only a stump on $\mathrm{M}_{4}$ vein.

Distribution: BRAZIL: MG (Alto Caparaó).

Remarks: Lane \& d'Andretta (1956) listed an additional 3 paratypes, they were not examined.

\section{Kelloggina timbira Lane \& d'Andretta, 1956} (Fig. 12)

Lane \& d'Andretta (1956: 201, fig. 15). Hogue (1971: 6).

Types in MZSP: HOLOTYPE (Fig. 12): $1 \sigma^{7}$ (\#MZ001867) from Brazil, RJ, Itatiaia, Cachoeira Bonita, 2,100 m a.s.l., III/1941, Lério Gomes coll. 
Diagnosis: Male (Fig. 12): General coloration black. Head: Front and clypeus dark brown. Eyes broadly separated; upper portion with nearly half the size of lower one. Antenna with 14 segments, scape, pedicel, and flagellum black. Proboscis distinctly longer than head. Palpus with four black segments. Thorax: Pronotum black. Scutum black, with three pruinose stripes in the middle. Scutellum black. Pleura dark brown. Legs: Coxae and trochanters yellow, femora yellow at base and darker apically, tibiae and tarsi light brown. Hind tibia with one spur. Hind last tarsal segment without a basal enlargement, only a small tuft of setae. Wing hyaline, with costal cell yellowish. Vein $\mathrm{m}-\mathrm{m}$ absent.

Distribution: BRAZIL: RJ (Itatiaia).

Remarks: Female unknown.

Kelloggina travassosi Lane \& d'Andretta, 1956 (Fig. 13)

Lane \& d'Andretta (1956: 202, fig. 16). Hogue (1971: 6).

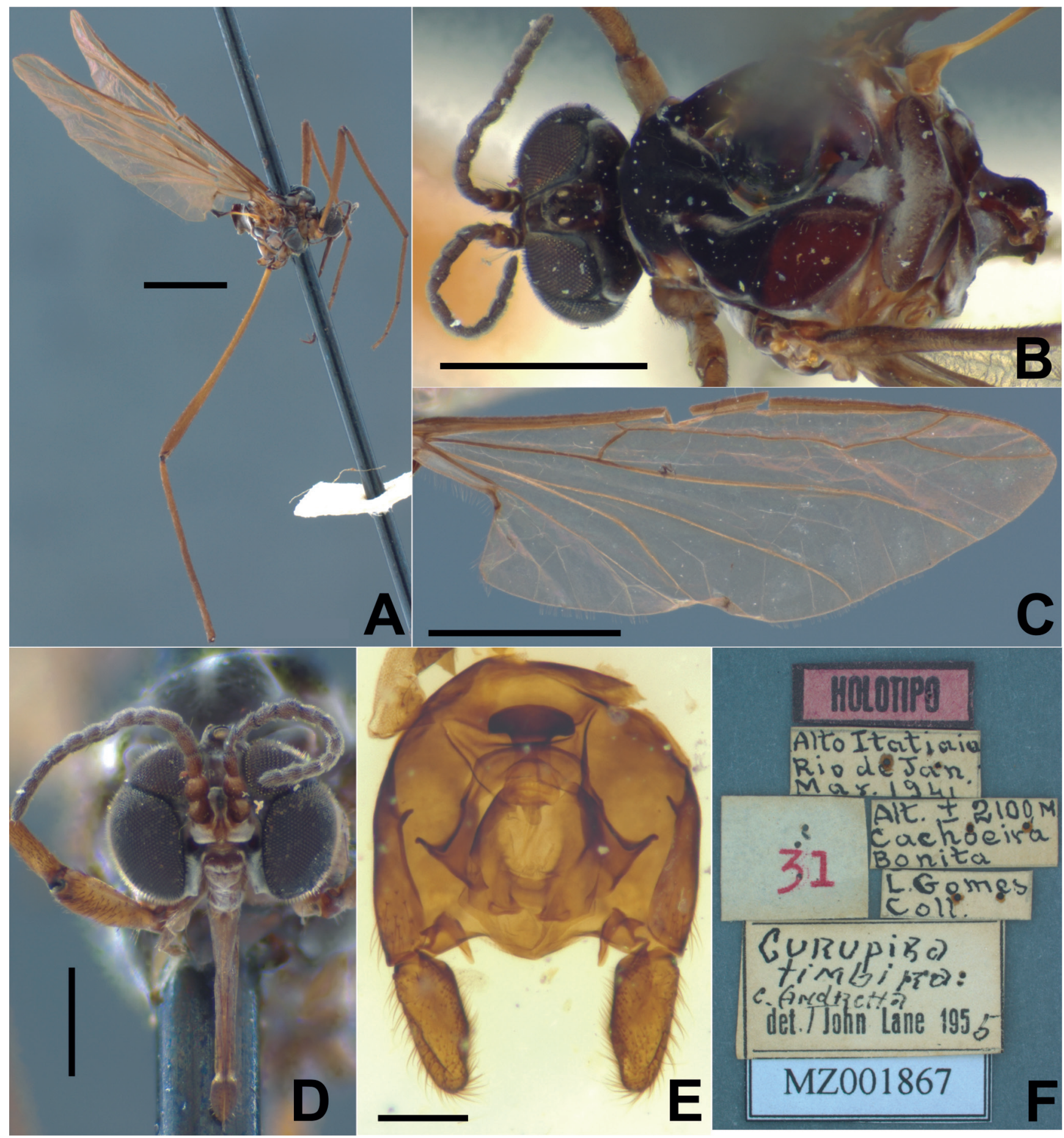

Figure 12. Holotype male of Kelloggina timbira Lane \& d'Andretta, 1956: (A) Habitus, lateral view; (B) Habitus, dorsal view; (C) Wing; (D) Head, frontal view; (E) Male terminalia; (F) Labels. Scale bars: $A, C=2 \mathrm{~mm} ; B=1 \mathrm{~mm} ; D=0.5 \mathrm{~mm} ; E=0.2 \mathrm{~mm}$. 
Types in MZSP: HOLOTYPE (Fig. 13): $10^{\pi}$ (\#MZ006741) from Brazil, SP, Santo Antônio do Pinhal, Eugênio Lefevre, 1,200 m a.s.l., II/1953, Lauro Travassos Filho coll.
Diagnosis: Male (Fig. 13): General coloration black. Head: Front and clypeus dark brown. Eyes broadly contiguous and narrowly separated above; upper portion

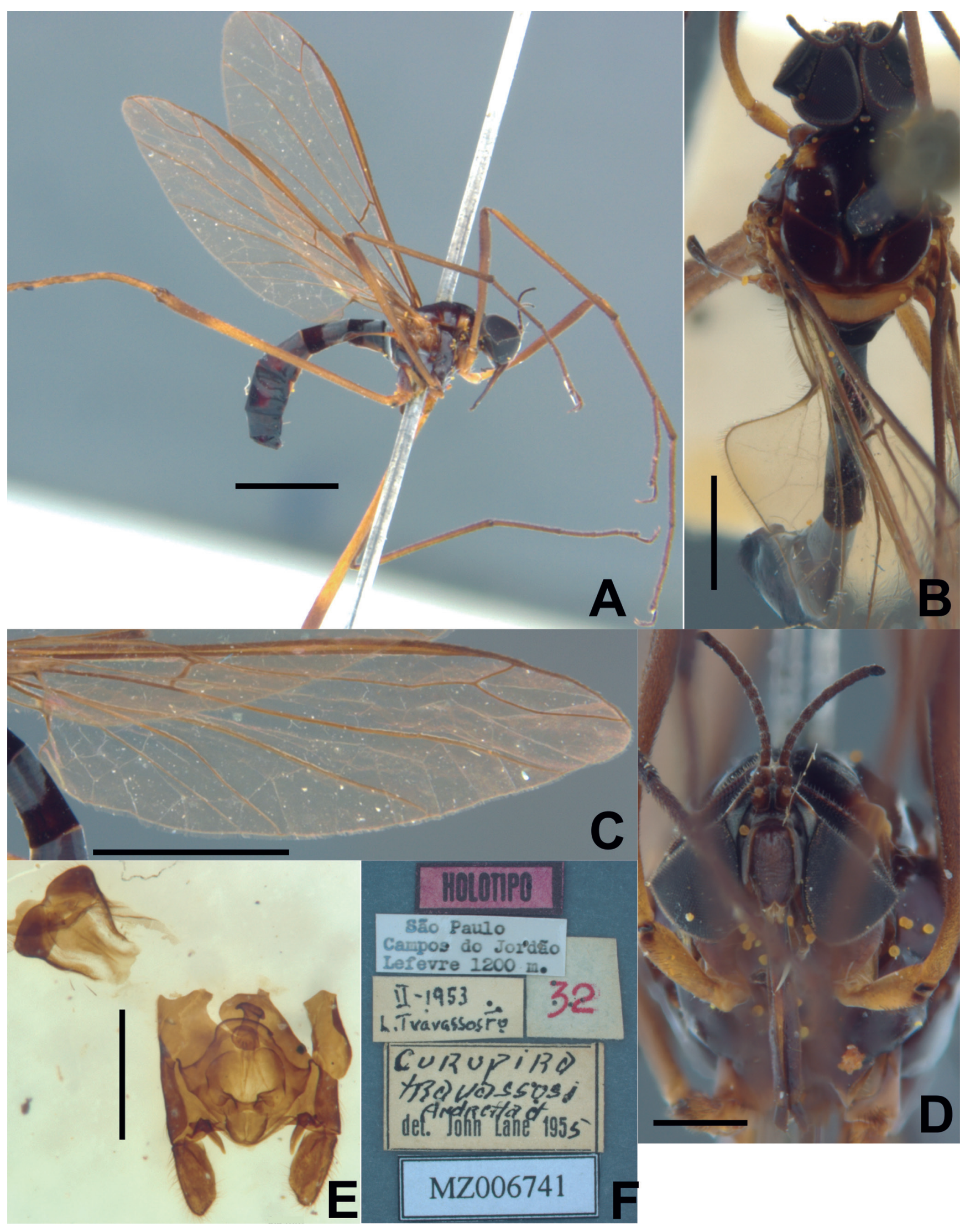

Figure 13. Holotype male of Kelloggina travassosi Lane \& d'Andretta, 1956: (A) Habitus, lateral view; (B) Habitus, dorsal view; (C) Wing; (D) Head, frontal view; (E) Male terminalia; (F) Labels. Scale bars: $A, C=2 \mathrm{~mm} ; B=1 \mathrm{~mm} ; D-E=0.5 \mathrm{~mm}$. 
quite larger than the lower one. Antenna with 14 segments, scape, pedicel and flagellum black. Proboscis distinctly longer than head. Palpus with four black segments. Thorax: Pronotum black. Scutum black, with $1+1$ thin antero-lateral yellow stripes. Scutellum yellow. Pleura dark brown with large yellow marks. Legs: Fore coxa orange, mid coxa orange and black, and hind coxa black. Trochanters yellow, femora and tibiae yellow at base and darker apically, tarsi light brown. Hind tibia with two spurs. Hind last tarsal segment with a bristly basal enlargement. Wing hyaline, with costal cell yellowish. Vein $\mathrm{m}$-m absent.

Distribution: BRAZIL: SP (Santo Antônio do Pinhal).

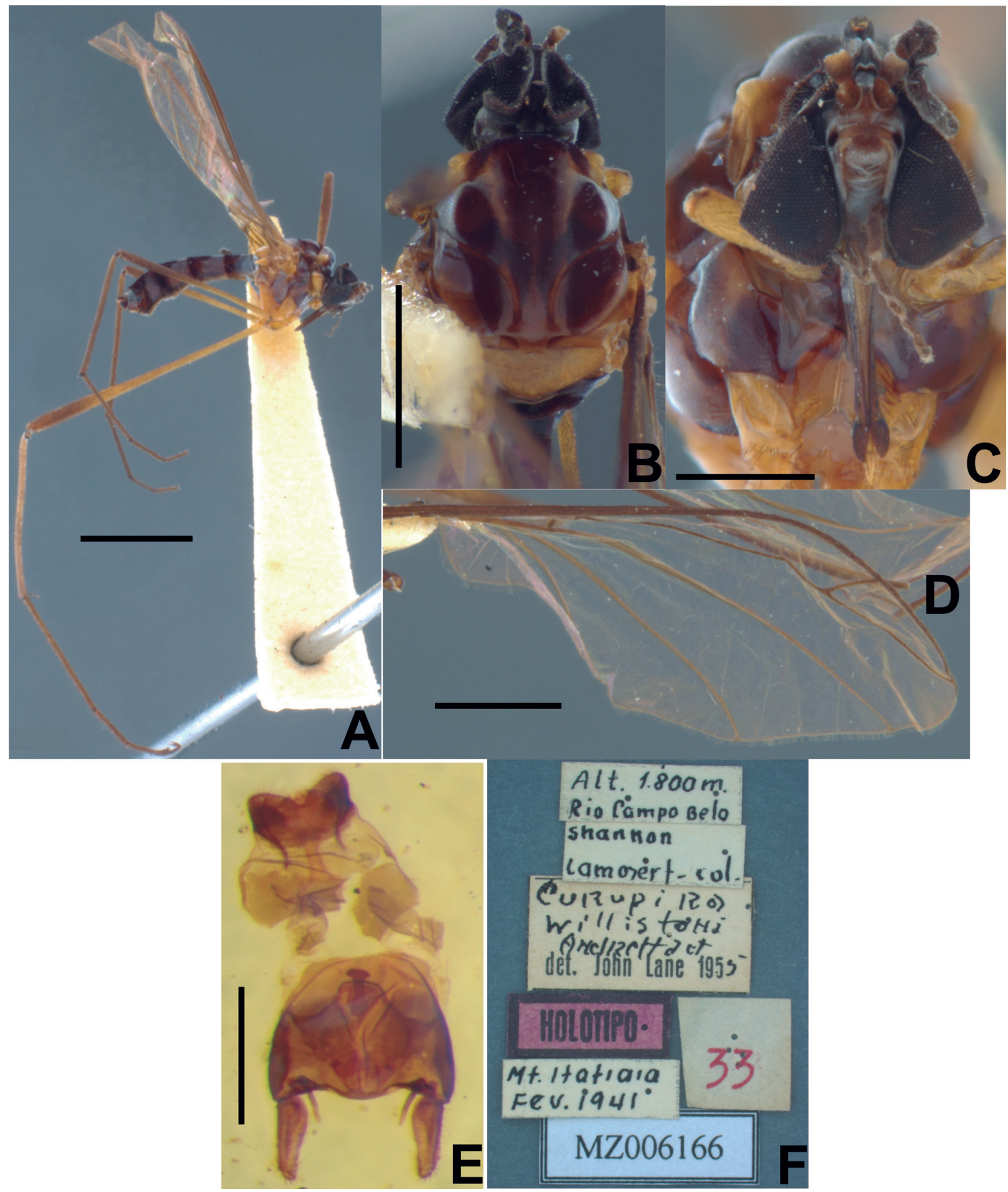

Figure 14. Holotype male of Kelloggina willistoni Lane \& d'Andretta, 1956: (A) Habitus, lateral view; (B) Habitus, dorsal view; (C) Head, frontal view; (D) Wing; (E) Male terminalia; (F) Labels. Scale bars: $A=2 \mathrm{~mm} ; B, D=1 \mathrm{~mm} ; C, E=0.5 \mathrm{~mm}$. 
Remarks: Female unknown. Lane \& d'Andretta (1956) cited holotype from (confirmed on the label): "Campos do Jordão, Eugênio Lefévre (1,200 m. alt.), ii.1953 (Travassos, col.)", but Eugênio Lefevre train station belongs to the Santo Antônio do Pinhal municipality and not to Campos do Jordão municipality.

\section{Kelloggina willistoni Lane \& d'Andretta, 1956} (Fig. 14)

Lane \& d'Andretta (1956: 202, fig. 17). Hogue (1971: 6).

Types in MZSP: HOLOTYPE (Fig. 14): 1 o" (\#MZ006166) from Brazil, RJ, Itatiaia, Rio Campo Bello, 1,800 m a.s.l., II/1941, Raymond C. Shannon \& Hugo Laemmert coll. PARATYPE: 1 \% (allotype), same data of holotype.

Diagnosis: Male (Fig. 14): General coloration brown. Head: Front and clypeus dark brown. Eyes broadly contiguous and narrowly separated above; upper portion quite larger than the lower one. Antenna with 14 segments, scape and pedicel brown, flagellum black. Proboscis slightly longer than head. Palpus with four black segments. Thorax: Pronotum dark brown. Scutum dark brown, with three pruinose stripes in the middle. Scutellum yellow. Pleura dark brown with large yellow marks. Legs: Coxae and trochanters yellow, femora yellow at base and darker apically, tibiae yellow, and tarsi light brown. Hind tibia with two spurs. Hind last tarsal segment with a bristly basal enlargement. Wing hyaline, with costal cell yellowish. Vein $\mathrm{m}-\mathrm{m}$ absent, only a stump on $\mathrm{M}_{4}$ vein.

Distribution: BRAZIL: RJ (Itatiaia).

Remarks: Lane \& d'Andretta (1956) listed an additional $5 \sigma^{7}$ and 69 paratypes. Two male and two female paratypes were lost during the MNRJ fire. The other $3 \sigma^{7}$ and 4 \& were not examined. Lane \& d'Andretta (1956) cited material from Itatiaia, Maromba, $100 \mathrm{~m}$ a.s.l., but it is probably an error in altitude number.

\section{DISCUSSION}

Males of the 14 species addressed here have in common: eyes divided into two parts (upper and lower portions); antenna with 12 flagellomeres; proboscis longer than head; and palp with four palpomeres. With this combination of characters, these species could be easily differentiated from other genera of Blepharicerinae in the Neotropical region, as Aposonalco Hogue, 1992, Limonicola Lutz, 1928, and Paltostoma Schiner, 1866. These characters should be further investigated in other species of Kelloggina, to confirm whether they are diagnostic for the genus.

The Lane \& d'Andretta's species can be differentiated from each other by somatic characters of the male as: eyes shape, proboscis length, number of tibial spurs, presence of wing transversal vein $\mathrm{m}-\mathrm{m}$, and coloration. We prefer not to use the male terminalia in the diagnoses because in the holotypes they were mounted in slides and became too two-dimensional, thus we are unable to see differences between them.

We have identified four groups of species that seem related, separated by coloration characters only: (1) K. cataguasi, K. gomesi, and K. shannoni. (2) K. cherentesi, K. laemmerti, and K. tapuiasi. (3) K. tamoioi and K. willistoni. (4) K. cataguasi and K. edwardsi. These species should be better investigated, with the addition of more data from male terminalia and immatures. For instance, $K$. cataguasi and $K$. edwardsi are remarkably similar, looking like yellow and black morphotypes/variants of the same species - they should be better compared, preferably with fresh material.

\section{ACKNOWLEDGMENTS}

We would like to thank Camila Fernandes Conti (MZSP) for the photos presented in this catalogue and also to the Conselho Nacional de Desenvolvimento Científico e Tecnológico (CNPq) for the research fellowship (302751/2019-0) to CJEL. This research was sponsored by CNPq (429959/2016-8, Edital Universal, to LHGA), by Fundação Carlos Chagas Filho de Amparo à Pesquisa do Estado do Rio de Janeiro (FAPERJ; E-26/200.083/2019, Apoio Emergencial ao Museu Nacional, to LHGA); and by the Coordenação de Aperfeiçoamento de Pessoal de Nível Superior - Brasil (CAPES; Finance Code 001, Aditivo emergencial ao Auxílio № 0721/2018 to PPGZoo, Programa PROEX).

\section{AUTHORS' CONTRIBUTIONS}

Leonardo H. Gil-Azevedo: Conceptualization, Data curation, Funding acquisition, Methodology, Investigation, Writing - original draft. Carlos José Einicker Lamas: Conceptualizartion, Data curation, Funding acquisition, Investigation, Writing - review \& editing.

\section{CONFLICTS OF INTEREST}

Authors declare there are no conflicts of interest.

\section{REFERENCES}

Alexander, C.P. 1958. Geographic distribution of the net-winged midges (Blepharoceridae, Diptera). In: International Congress of Entomology, $10^{\circ}$. Proceedings. Montreal. v. 1, p. 813-828, 1956.

Courtney, G.W. 2017. Blephariceridae (Net-winged midges or Torrent Midges). In: Kirk-Spriggs, A.H. \& Sinclair, B.J. (Eds.). Manual of Afrotropical Diptera. Vol. 2. Nematocerous Diptera and lower Brachycera. Suricata 5. Pretoria, South Africa National Biodiversity Institute. p. 487-496.

Falaschi, R.L.; Oliveira, S.S. \& Lamas, C.J.E. 2018. Catalogue of Bibionidae (Diptera: Bibionomorpha) types housed in the collection of the Museu de 
Zoologia da Universidade de São Paulo, Brazil. Papéis Avulsos de Zoologia, 58(27): 1-5. DOI

Gil-Azevedo, L.H. 2018. Family Blephariceridae.Chapter 16.9.In:Hamada,N.;.Thorp J.H. \& Rogers, D.C. (Eds.). Keys to Neotropical Hexapoda, Thorp and Covich's Freshwater Invertebrates. Vol. 3. London, Academic Press. p. 759-763. D0I

Hogue, C.L. 1971. Family Blephariceridae. In: Papavero, N. (Ed.). Catalogue of the Diptera of the Americas South of the United States, n. 8. São Paulo, Museu de Zoologia, Universidade de São Paulo. 12p.

Lane, J. \& d'Andretta-Jr., C. 1956. Brazilian Blepharoceridae (Diptera, Nematocera). Annals and Magazine of Natural History, Series 12, 9: 117-201.
Lutz, A. 1920. Dípteros da família Blepharoceridae, observados no Brazil. Memórias do Instituto Oswaldo Cruz, 4: 75-83.

Williston, S.W. 1893. Diptera Brasiliana. Part III. A new genus of Blepharoceridae. Kansas University Quarterly, 1: 119-120.

Williston, S.W. 1896. On the Diptera of St. Vicent (West Indies). Transactions of the Entomological Society of London, 1896: 253-446.

Williston, S.W. 1907. Dipterological notes. Journal of the New York Entomological Society, 15: 1-2. 